\title{
The Borelli Doctrine Revisited: Three Issues of Coherence in a Landmark Ruling for EU Administrative Justice
}

Filipe Brito Bastos*

PhD Candidate, European University Institute

\section{Abstract}

The aim of this article is to examine through the lens of coherence the doctrine established in the Borelli case-law, which has become a landmark case in administrative justice concerning bottom-up composite procedures. This paper will address three common issues relating to the coherence of the Borelli doctrine. First, its coherence with regard to important principles of EU constitutional law, such as the right to effective judicial protection. Second, the issue of the coherence of the criteria of judicial review established by Borelli for national measures with the criteria used by the Court when it is required to assess the legality of EU measures. Third, the discrepancy, illustrated by the Borelli case, between the institutional reality of EU composite administration and the EU system of administrative justice.

The paper submits that the Borelli doctrine, which I argue entails two distinct principles, must be placed in the constitutional context in which it was developed. I aim to support the claim that Borelli is, in itself, a coherent solution for the problem it addresses, and that the source of its insufficiencies is not in the case law, but rather in the EU's system of administrative justice itself.

\section{Introduction: Three Issues of Coherence}

On the eve of approaching a quarter of a century after it was delivered, the Borelli ruling still shows its enduring relevance and vitality in legal practice and academic debate. ${ }^{1}$ To this day, European Union (EU) courts and legal scholars continuously find new applications for this landmark ruling in the field of EU administrative law. ${ }^{2}$ However, Borelli typically carries quite different connotations depending upon whether EU courts or legal scholars are referencing the case.

For the Court of Justice (CJEU), the General Court (GC) and its predecessor the Court of First Instance (CFI), Borelli represents two things. On the one

* DOI 10.7590/187479815X14465419060622

\section{Case C-97/91 Oleificio Borelli [1992] ECR I-06313.}

2 See, for just a few instances of recent explorations of the uses of Borelli, L. Wissink,

T. Duijkersloot \& R. Widdershoven, 'Shifts in Competences between Member States and the EU in the New Supervisory System for Credit Institutions and their Consequences for Judicial Protection', in: Utrecht L Rev. (2014), 92 ff, 97, B. Marchetti, 'Il Sistema integrato di tutela', in: L. de Lucia \& B. Marcheti, L'amministrazione europea e le sue regole, il Mulino (2015), $197 \mathrm{ff}$, especially $221 \mathrm{ff}$ and L. de Lucia, 'Amministrazione Europea e tutela giurisdizionale', in: M. Chiti 
hand, Borelli represents a doctrine that should guide national and European courts in actions for annulment against measures resulting from bottom-up administrative procedures. ${ }^{3}$ As we will examine below, this doctrine consists of what are in effect two distinct principles, which are meant to solve the issue of gaps within judicial protection that result from the plurality of jurisdictions and legal orders existing in the EU's multilevel administration.

The second thing Borelli represents, from the perspective of European courts, is effective judicial protection. Indeed, Borelli has been abundantly quoted in further rulings as an illustration of how the EU respects effective judicial protection as a fundamental right and a crucial constitutional principle. ${ }^{4}$

From the point of view of academic commentary, Borelli carries a very different meaning. First, it stands not for respect, but for the denial of the fundamental right to effective judicial protection. Therefore, it is seen to be in contradiction with the demands placed by EU constitutional law on the administration of justice both before domestic and EU courts alike. Secondly, Borelli allegedly suggests that the Court displays double standards in regard to the issue of reviewability of intermediate procedural measures, as it purportedly demands from national courts that they review domestic measures which, under analogous circumstances involving EU legal acts, it would itself refuse to review. Thirdly, rather than being the expression of a complete and coherent system of judicial protection, Borelli betrays the extent to which the current system of European administrative justice is ill-suited to deal with the instances of mixed decisionmaking, which have multiplied in the EU legal landscape over the past decades. In other words, there may be a mismatch between the institutional and substantive reality of the EU multi-layered administration and its remedial and judicial architecture. Therefore, commentators argue, the system is in need of reform. ${ }^{5}$

\& A. Natalini, Lo Spazio amministrativo europeo: Le Pubbliche Amministrazioni dopo il Trattato di Lisbona (Bologna 2012), $355 \mathrm{ff.}$

3 On the concept of composite procedure, and on its different classifications, see S. Cassese, 'European Administrative Proceedings', Law Q Contemp. Probs. (2004-2005), 21 ff., M. Chiti, 'I procedimenti composti nel diritto comunitario e nel diritto interno', in: Quaderni del Consiglio di Stato: Attività amministrativa e tutela degli interessati. L’influenza del diritto comunitário, Giappichelli (Turin 1997), 55 ff and G. della Cananea, 'The European Union's mixed administrative proceedings', Law and Contemp. Problems (2004-2005), 197 ff. Composite procedures are often said to be of the bottom-up type when they involve successive interdependent decisional input from domestic and EU bodies, and to be of the top-down type when they begin at EU level and then 'descend' to the national level. For further, more nuanced classifications that go beyond this classic distinction, see M. Eliantonio, 'Judicial Review in an Integrated Administration: the Case of Composite Procedures', REALaw (2014/2), $65 \mathrm{ff}$.

4 See, for instance, Cases C-424/99 Commission v. Austria [2001] ECR I-9285, \45, C-50/00 P Unión de Pequeños Agricultores [2002] ECR I-6677, 『39, T-315/01 Kadi [2005] ECR II-03649, $\int 210$ and C-562/12 Livimaa [2014], \75.

5 See H. Hofmann, 'Composite decision making procedures in EU administrative law', in: H. Hofmann \& A. Türk, Legal Challenges in EU Administrative Law: towards an integrated administration' (Cheltenham 2009), 136 ff, 166 ff. 
These three questions can intuitively be seen as problems of coherence within EU administrative law that are specifically raised by some kinds of bottom-up composite procedures. But in order to confirm whether these three questions really are about legal coherence, we require a sharper understanding of coherence as a starting point for their discussion. Yet, it appears that the concept of coherence itself may well be one of the most controversial in legal theory and philosophy. ${ }^{6}$ My aim is not to be a participant in this debate, but rather an observer, thereby drawing from it only some key concepts that may help us in examining whether the three issues mentioned above are questions of coherence, and if so, how we may answer them.

As one author points out, scholarly discussion on the definition of coherence has tended to end in theoretical capitulation by claiming coherence is too complex a term to be defined. ${ }^{7}$ However, there are many different meanings that coherence can take, which are summarised by Kress, who states: 'an idea or theory is coherent (...) if it hangs or fits together, if its parts are mutually supportive, if it is intelligible, if it flows from or expresses a single unified viewpoint'. ${ }^{8}$ One should not, however, overstate the importance of intelligibility, which is often mistaken to be a necessary element of coherence altogether when in fact it is merely a necessary element of many objects whose coherence is tested. ${ }^{9}$ Rather, as Pethick suggests, ${ }^{10}$ in the conceptual delimitation of coherence we should take as point of departure its most intuitive notion, which is closest to its everyday usage in our natural language. ${ }^{11}$ Coherence can be both a property of an object - a version of a story can be internally coherent - and a type of relationship between two objects - two versions of a story can cohere with each other. More generally, coherence is used in the sense of composite parts of a single object or different related objects 'sticking together', meaning that they mutually and symmetrically fit together as a whole. Coherence must further be distinguished from consistency. Consistency is about the absence of contradictions whereas coherence is a function of the (variable) extent to which a set of propositions makes sense when taken together. ${ }^{12}$

6 I am indebted to Professor Stephen Pethick for raising attention to the intense theoretical controversies on coherence.

7 Stephen Pethick, 'On the Entanglement of Coherence', in: Ratio Juris (2014), 116 ff, 125 and 128.

8 K. Kress, 'Coherence', in: D. Patterson, A Companion to Philosophy of Law and Legal Theory, and ed. (Chichester 2010), $521 \mathrm{ff}, 521$.

9 S. Pethick (n 7), 125.

10 See S. Pethick (n 7), 128-130.

11 For a different perspective, see A. Aarnio, Essays on the Doctrinal Study of Law (Dordrecht 2011), 144-146 and R. Alexy \& A. Peczenik, 'The Concept of Coherence and its Significance for Discursive Rationality', in: Ratio Juris (1990), 130 ff.

12 N. MacCormick, Rhetoric and the Rule of Law (Oxford 2005), 190. 
The Borelli doctrine raises, in particular, doubts about normative coherence. ${ }^{13}$ Normative coherence concerns the justifiability of legal propositions by reference to their broader context in the legal system, and in particular under higher-order principles and values. ${ }^{14}$ Normative coherence thus depends on the possibility to justify legal propositions as situated in a continuum with the pre-existing body of law, and as derivable from the binding rules of the system..$^{15}$ Drawing inspiration from Dworkin's work, and the idea of law as integrity, one could say that interpreters must make their interpretive claims on legal provisions based on 'the assumption that they were all created by a single author - the community personified - expressing a coherent conception of justice and fairness' ${ }^{16}$ Interpretation thus becomes like the continuous writing of a chain novel by relying on the materials previously laid out by others and respecting the overall unity of the narrative. ${ }^{17}$ In this contribution, after recapitulating the facts and the solutions in the case and clarifying the scope of the Court's findings, three claims will successively be made. One claim for each reservation made by legal scholars to the Borelli doctrine that were identified above, and which can now be understood as three different issues of coherence.

The first problem is that the same Court that constitutionalised EU law, and in particular incorporated into it the fundamental right to effective judicial protection, decided Borelli by denying judicial protection to the applicant. To this respect, there is one insight we can gain from the metaphors of the chain novel or of a sole hypothetical author that is guided by the same principles. Namely, it may lead us to unveil the puzzle of whether the Borelli doctrine represents, in EU administrative law, the continuity or disruption of EU law's previous 'constitutional chapters'. Therefore, in other words, whether the Borelli doctrine and the Court's essential constitutional doctrines are mutually supportive and fit together. In this regard, I will defend that, in developing the Borelli doctrine, the CJEU articulated a possible way out of the strict dualistic structure of EU administrative law. A way out that was both defensible and indeed coherent in the light of fundamental principles built up in the CJEU's previous constitutionalising case law.

The second problem concerns the criteria of reviewability of national intermediate measures in Borelli situations. It concerns whether these criteria are convincingly argued as standing in continuity with the CJEU's earlier under-

Normative coherence is to be distinguished from narrative coherence, which concerns the 'justification of findings of fact and the drawing of reasonable inferences from evidence'. The distinction is drawn by N. MacCormick (n 12) 189 .

14 N. MacCormick (n 12), 193.

15 F. Carbonell, 'Coherence and Post-Sovereign Legal Argumentation', in: A.J. Menéndez \& J.E. Fossum, The Post-Sovereign Constellation: Law and Democracy in Neil D. MacCormick's legal and political theory (Oslo 2008), $109 \mathrm{ff}, 124$.

16 R. Dworkin, Law's Empire (London 1986), 217 ff, 225.

17 Idem, $228 \mathrm{ff}$. 
standing of the criteria that the need for an appropriate level of judicial protection dictates for the review of EU measures. I will challenge the claim that the Borelli doctrine suggests a double standard by submitting the exact opposite - that it can actually be seen as an instance of what has been called vertical equivalence.

The third problem, unlike the previous two, does not relate to the interpretive coherence of judges in regard to pre-existing sources, but to the coherence of institutional, procedural and remedial dimensions of EU administrative law. Here, one may question whether the basic principles guiding the EU's model of administrative justice are the same as those which underpin the structure of composite procedures. While that model is meant for measures and actions that are unambiguously imputable to the national or EU administrative spheres, composite procedures are founded on decisional hybridity. Here, I will agree to the frequent claim that Borelli exposes a system of administrative justice that has been outgrown by the EU's current administrative institutional reality, and I will examine how, for as long as substantial revision of the Treaties does not take place, we could address the concerns arsing in Borelli.

\section{Borelli: the Facts and the Doctrine. The Jurisdictional and the Substantive Borelli Principles}

The Borelli Case can be said to be the seminal judgment in the law of composite procedures. It is often said to have been the first time that the problems of articulation between European and national courts in reviewing hybrid decision-making were addressed. ${ }^{18}$

An Italian company requested funding from the Guidance Section of the European Agricultural Guidance and Guarantee Fund (EAGGF) in order to build an oil mill. Under Regulation 355/77, it was the role of national authorities to assess whether projects conformed with the requirements for the disbursement of funds. As each project had to be co-funded by the EU and by the Member State in which it would be carried out, the granting of aid by the Commission depended on the issue of a positive opinion by the relevant national authority, ${ }^{19}$ in the case, the Region of Liguria.

Upon receiving a negative opinion, the Commission informed the applicants that their request was denied. The latter sought to challenge the Commission's decision before the CJEU, claiming that the Italian administrative measure on

18 R. Caranta, 'Sull'impugnabilità degli atti endoprocedimentali adottati dalle autorità nazionali nelle ipotesi di coamministrazione', Il Foro amministrativo (1994), 752 ff and L. Maeso Seco, 'I Procedimenti Composti Comunitari: Riflessioni Intorno alla Problematica della Impossibilità a Difendersi ed Eventuali Alternative', in: G. della Cananea \& M. Gnes, I Procedimenti Amministrativi dell'Unione Europea. Un'Indagine (Turin 2004), $11 \mathrm{ff}$.

19 Articles 17 and 13(3) of the Regulation. 
which it was based was illegal. Liguria had allegedly performed an erroneous assessment of the contracts between Borelli and its olive producers by concluding that they neither showed enough guarantees of authenticity, nor ensured a lasting share of the economic benefits resulting from the project. These were among the requirements to be met for the aid to be granted.

The company argued that the Court had to accept the challenge of the Commission's final act, since Liguria's negative opinion was qualified in Italian law as a preparatory measure, and therefore excluded from judicial review. Borelli argued that a final decision adopted in such conditions should be annulled, as it 'encapsulates all the decisions of the institutions and bodies involved in the procedure' and absorbs in itself the irregularity of intermediate acts.

In essence, the Court followed the opinion of Advocate General (AG) Darmon in its answer. An answer that entails both judicial procedural and substantive elements. Given the fact that those two dimensions were applied and adapted separately in subsequent judgments, I will refer to them as the jurisdictional and the substantive Borelli principles, respectively. These refer to two basic issues in any action for annulment. The first, the jurisdictional Borelli principle, concerns the identification of the competent judiciary who can review a measure. The second Borelli principle relates to the grounds for its invalidity and, more specifically, to the invalidating relevance of irregularities occurring throughout the procedure. Together, the two principles form what I will call the Borelli doctrine.

The jurisdictionalBorelli principle is found in the CJEU's and the AG's ${ }^{2 \circ}$ claim that it is the task of national courts to review the validity of intermediate domestic measures that leave no discretion to EU bodies. When measures such as binding opinions determine in themselves the final outcome of the procedure and are 'capable of adversely affecting third parties', they must be subject to judicial review before national courts, on 'the same terms on which they review any definitive measure adopted by the same national authority. ${ }^{21}$ As AG Darmon explained, measures such as Liguria's binding negative opinion entail definitive adverse effects by necessarily determining what the final decision of the Commission will be. Therefore, in the light of effective judicial protection, they must be open to judicial review. ${ }^{22}$ Should national remedial law obstruct the challenge of the measure, individuals may raise a preliminary question before national courts for referral to the ECJ. ${ }^{23}$ It should be noted that in subsequent rulings the CFI stressed that the refusal to accept annulment claims against intermediate measures such as the ones in Borelli would constitute cause for actions for in-

20 AG Darmon in C-97/91, Borelli, $\iint 32-33$.

21 Borelli, $\int \mathbb{\int} 10$ and 13 .

22 AG Darmon in Borelli, $\int \mathbb{\int} 32$ and 33.

23 Ibid., $\mathbb{3} 33$. 
fringement against the relevant Member State. ${ }^{24}$ Ultimately, as the CJEU is not competent to interpret or apply national law, it cannot review an interlocutory national measure when assessing the validity of the final Commission decision. This is so even if the content of that decision is predetermined by the interlocutory measure

The starting point for what I call the substantiveBorelli principle is precisely that the Court cannot apply or review national measures. ${ }^{25}$ The consequences of this for final decisions, of the Commission, that depend on national intermediate measures are implicit in AG Darmon's opinion, ${ }^{26}$ but explicit in the Judgment. The Court cannot decide on grounds of national law or assess the validity of national measures to conclude whether a decision of the Commission is invalid. In the Borelli case, this led the Court to adhere to the view that '[an] irregularity that might affect the opinion cannot affect the validity of the decision by which the Commission refused the aid applied for' ${ }^{27}$ In other words, the substantive Borelli principle represents the rejection of contagion effects extending procedural illegality from the domestic to the EU procedural stage. Put differently, the substantive Borelli principle forbids national interlocutory measures to become a sort of Trojan horses that transports their invalidity into the body of EU law.

From this it should become clear that in Borelli the Court actually stated two different things. First, that national courts should review at least some types of interlocutory national measures in composite procedures and second, that those measures' procedural illegality could not contaminate the lawfulness of the final EU decision. This solution, which other AGs have admitted to be 'harsh', ${ }^{28}$ seems to echo the Commission's understanding that the final decision challenged by Borelli 'was drawn up in the context of two distinct legal systems' (emphasis added). ${ }^{29}$ Yet at the same time, echoing AG Darmon's rejection of the undertaking's application because it failed to demonstrate that the decision of the Commission suffered from any defectiveness of its own (vice propre). To be invalid, that Commission decision would have had to have breached a rule of EU law.

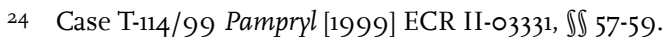

25 Borelli, $\int 9$.

26 Ibid., $\ 34$.

27 Borelli, \12. See also T-215/O7 R Donnini [2007] ECR II-04673, \91 and Pampryl, \57.

28 AG Mischo in C-6/99 Association Greenpeace France (see below, at 39) \98.

29 Report for Hearing, I-6321. 


\section{The Versatility and the Scope of the Borelli Doctrine}

It should be noted that the ruling in Borelli was delivered in the light of legislation on the granting of EAGGF agricultural aids that is nowadays repealed. Nevertheless, in subsequent case law, the EU judicature showed the versatility of the Borelli doctrine by applying it to other bottom-up composite procedures in the area of Protected Designations of Origin (PDOs) and Geographic Indications (GIs).

The continuous use of the two Borelli principles in disputes located in such wholly unrelated policy fields demonstrates that they form a generalisable doctrine of EU administrative law, which aims at solving issues of annulment in some instances of hybrid decision-making. Borelli constitutes a doctrine whose scope of application is not conditional upon the substantive standards for decision-making enshrined in the relevant sectorial legislation, but solely upon the structural properties of the administrative procedures aimed at implementing them.

In light of the case law of the CJEU, the key criterion to determine whether the Borelli principles ought to be applied remains twofold. First, a national authority must have adopted an administrative measure which, according to the relevant EU legislation, 'formspart of a Community decision-making procedure' (emphasis added)..$^{30}$ Secondly, and cumulatively, the Borelli doctrine requires that such a measure 'is binding on the Community decision-taking authority and therefore determines the terms of the Community decision to be adopted..$^{11}$ In later cases, relating to the field of PDOs and GIs, the Court paraphrased the original formula and confirmed the two conditions by maintaining that the Borelli doctrine can be used solely to challenge a national interlocutory act 'which constitutes a necessary step in the procedure for adoption of a Community measure, [and in regard to which] the Community institutions have only a limited or non-existent discretion'..$^{2}$

The restriction of the scope of the Borelli doctrine to composite procedures does not always seem to be recognized. There is nothing in the case-law suggesting that the Court regards the national limitations to the object of annulment proceedings to final measures as per se contrary to effective judicial protection. A spill-over effect to non-composite procedures in national laws is neither a demand nor an implication of the Borelli line of case-law. This is however what García de Enterría assumes when he accuses the Court of having taken the role of a lawmaker by eliminating national rules restricting the object of annulment claims to final measures and thus expanded national courts' jurisdiction beyond their legislative definition (E. García de Enterría, 'La ampliación de la competencia de las jurisdicciones contencioso-administrativas nacionales por obra del Derecho Comunitario. Sentencia Borelli de 3 de diciembre de 1992 del Tribunal de Justicia y el artículo 5 CEE', Revista Española de Derecho Administrativo (1993), $297 \mathrm{ff}, 304$ and 311$)$.

31 Borelli, at $\$ 10$.

32 C-269/99 Carl Kühne [2001] ECR I-09517, \57. This was the line of reasoning followed in other rulings on the PDO and GI registration procedure. See Case C-343/07 Bavaria NV [2009] ECR I-05491, at $\iint 55-7$ and 64-67. 
The Borelli doctrine shows great versatility, as its scope can be positively defined as encompassing all administrative procedures following a structure that fulfils these two conditions. Beyond the field of PDOs and GIs, ${ }^{33}$ the wide variety of procedures relating to the administration of EU tariff quotas displays a multitude of situations in which the Borelli principles may easily find application. ${ }^{34}$

The same criterion of disparity in the allocation of discretion within bottomup procedures can also be used to determine the ambit of the Borelli doctrine in a negative sense, i.e., situations that do not fall under its scope.

This is confirmed in the CJEU's line of reasoning in subsequent cases in which litigants unsuccessfully attempted to use the Borelli doctrine in an administrative procedure that did not display the structural properties required by the Borelli case law. In Association Greenpeace France, a case relating to the general authorisation framework for the placing of GMO products on the market, ${ }^{35}$ the

33 In the field of the registration of protected designations of origin and geographical indications, once national authorities submit names of traditional guaranteed specialities already registered in accordance to domestic law, the Commission has no choice but to register them as EU-wide protected specialities (Article 26 of Regulation No 1151/2012 of the European Parliament and the Council).

34 See Commission Regulation No 969/2006 of 29 June 2006, opening and providing for the administration of a Community tariff quota for imports of maize from third countries, and Commission Regulation No 2305/2003, of 29 December, opening and providing for the administration of a Community tariff quota for imports of barley from third countries. In both instruments, national authorities receive applications for import licences and submit to the Commission a list of those that they find eligible. The only major difference in structure of procedural stages, in comparison to the PDO and GI registration procedures, and to the procedure at hand in Borelli, is that the formal final measures are adopted by the national authorities after the Commission has exercised its role. However, in procedures of this kind, the decisional discretion to shape the final decision, like in the previously described administrative procedures, is exercised in the first, national stage of the procedure. By contrast, the last, national measure in the procedure carries no decisional weight and the Commission only checks whether traders have not defrauded the quota mechanism by submitting their applications to the authorities of more than one Member State. This was already noted by the Court in Joined Cases C-106/90, C-317/90 and C-129/91 Emerald Meats [1993] ECR I-00209, \35. In this ruling, while not referring to Borelli, the Court considered that the interlocutory national measure proposing the lists of licence holders should be reviewed before national, not EU courts - and can therefore be seen as a further example of applicability of the jurisdictional Borelli principle.

35 The procedure for the authorisation to the placing on the market of GMO products established in Directive 90/220, which is still essentially the same under Directive 2001/18, begins with the assessment of public health and environmental risks by national authorities of the Member State in which the product is to be first placed on the market. A negative result will immediately terminate the procedure. Otherwise, the authority sends to the Commission a positive assessment report with all the information the notifier has provided. The Commission will then open a multilateral stage by distributing the report to all the other relevant national authorities, which may then lodge objections to the issue of the authorisation. The absence of objections from other Member States will count as tacit consent and the first authority ends the procedure by giving its 'consent in writing' to the notifier. However, an objection will trigger a European dispute settlement stage in which the Commission will decide on the matter. If the Commission then decides to authorise the placing on the market of the GMO product, the first national authority issues its consent in writing. 
CJEU examined whether national intermediate measures in such a procedure could, on the one hand, determine the invalidity of the Commission's final decision if they were themselves invalid and, on the other hand, whether they could be the object of a separate judicial review. ${ }^{36}$

As AG Mischo explained, ${ }^{37}$

'unlike the situation that obtained in Oleificio Borelli (...), we do not have an unfavourable national decision, which would necessarily have led to an unfavourable decision by the Community, but on the contrary a favourable one, which (...) did not automatically entail a favourable decision by the Community but did make it possible' (emphasis added).

Following the AG's reasoning, the Court ended up admitting that the Commission's decision could, under certain conditions, be invalid on the ground that the preceding national measure was invalid, thus excluding the application of the substantive Borelli principle.

However, in what would at first sight appear to be a contradiction, the jurisdictional Borelli principle still found application as the CJEU explicitly stated that the first measure could be challenged before national courts. The reason is that, in the context of the general GMO authorisation scheme, the decisiveness of the intermediate national positive report for the content of the final decision will depend on circumstances that its issuing authority cannot control or predict at the time in which it decides (i.e., whether authorities from other states will object). Indeed, as the CJEU recognised, the 'decision of the competent authority is the prerequisite for the Community procedure and, in the absence of any indication to the contrary from another Member State (...), may even determine its outcome' (emphasis added).$^{38}$ If that interlocutory decision is not judicially challenged by citizens, but objected to by other authorities, then the EU stage is opened. Questions of eventual contamination effects from a preceding illegal draft domestic measure can only arise once a decision is adopted through the exercise of the Commission's discretion. However, if no objections are raised, the rapporteur national authority's will issue at the conclusion of the procedure a final decision whose content will mirror the findings of its prior positive assessment report. This differentiation from Borelli in Association Greenpeace France, in which the substantive dimension of Borelli is excluded, but the jurisdictional dimension is not, can be assumed to be valid for many authorisation schemes that follow fundamentally the same procedural structure. ${ }^{39}$

36 See C-99 Association Greenpeace France [2000] ECR I-01651.

37 See $\mathbb{1} 100$ of his Opinion in the judgment.

38 See Association Greenpeace France, \51.

39 See Article 29 of Directive 2001/82/EC of the European Parliament and of the Council of 6 November 2001 on the Community code relating to veterinary medicinal products, Article 33 of Directive 2001/83/EC of 6 November of the European Parliament and the Council on the Community code relating to medicinal products for human, Article $36(1)$ of Regulation 528/2012 
Judgments such as Greenpeace France confirmed the conditions for the application of the Borelli doctrine and made clear that litigants cannot rely on its two principles when national intermediate administrative measures do not predetermine the substance of decisional outcomes in subsequent procedural phases. ${ }^{4^{\circ}}$ Though I will only examine in sections 4 and 5 what would justify this differentiation, it is crucial to highlight for now that EU courts, when developing the Borelli doctrine, have insisted on the importance of the degree to which the national, interlocutory measures, bind the ensuing decision-taking EU body. For this reason, and at least partly, I must depart from the view supported by authors such as Eliantonio. Eliantonio considers that the reasoning in Borelli applies to all measures constituting 'mere preparatory steps', without distinction as to whether such measures may be overturned in subsequent stages unfolding before EU authorities, whether they only bear effects within the procedure, or whether they predetermine the content of its final decisional outcome in the procedure. ${ }^{41}$

I agree with Eliantonio on the scope of the jurisdictional dimension of Borelli concerning those national draft authorisations that one finds in the relevant procedure for the introduction of novel foods into the internal market. Indeed, as was explained above, this would follow from a straightforward application of the Court's findings in Association Greenpeace France. ${ }^{42}$ However, I must depart from the consideration that, as a consequence of the Borelli case law, the objections raised by other national authorities to the draft measure of the rapporteur national authority should be held as reviewable. ${ }^{43}$ The reason for this

of the European Parliament and the Council concerning the placing on the market and the use of biocides and Article 7(1) of Regulation 258/97 of the European Parliament and of the Council of 27 January 1997 concerning novel foods and novel food ingredients (novel foods and food ingredients. On the tendency for the use typical composite procedural models in different policy fields, see D. di Pretis, 'Procedimenti amministrativi nazionali e procedimenti amministrativi europei’, in: G. Falcon (Ed), Il procedimento amministrativo nei diritti europei e nel diritto comunitario (Padova 2008), 49 ff, 66.

40 See H.P. Nehl, 'Legal Protection in the Field of EU Funds', in: Eur. St. Aid L.Q. (2011), 629 ff, $648 \mathrm{ff}$, who also holds that the Borelli ruling's potential scope of application is limited to bottomup composite procedures where the EU body does not have discretion.

${ }^{41}$ See M. Eliantonio (n 3), in particular 91-96. Eliantonio's considerations are based on the Court's concern with the risks for effective judicial protection that would arise if the negative opinion in Borelli were not held as reviewable (at 83). However, as will be discussed in the next section, such risks arise fundamentally in situations where the Court, in assessing EU legal acts, would need to look into national procedural irregularities, and simultaneously be barred from doing so by the limits of its own jurisdiction. This problem does not arise when the EU judiciary does not need to go beyond evaluating the conformity with EU law of the acts of an EU body that authoritatively defines the content of the challenged measure in the composite procedure. In that case, the irregularities are fully imputable to the EU authority, and direct action under Article 263 TFEU becomes possible.

$4^{2}$ As set out before (see $\mathrm{n}$ 39), this is an administrative procedure which follows in essence the same structure as the procedure in the case.

43 See M. Eliantonio (n 3), at 94. 
is that such measures of objection have no other effect than triggering a new procedural stage. Such objections will not bind the body deciding in the new stage to give any specific content to the final measure.

Wissink, Duijkersloot, and Widdershoven seem to adhere to the alternative reading of Borelli's scope that is adopted here. ${ }^{44}$ These authors, while exploring the potential of Borelli in the fairly recent legal instruments of the Single Supervisory Mechanism (SSM), admit an a fortiori application of what I termed the jurisdictional Borelli principle to the rejection of applications for authorisations to set up credit institutions. ${ }^{45}$ Such rejections occur through the issue of negative decisions by the national competent authorities in banking supervision, and effectively terminate the procedure. However, the three authors do not extend the same considerations to the positive decisions by which those authorities establish the conformity of the applications with national law, the adoption of those decisions constituting a prerequisite for the opening of the following procedural stage taking place before the European Central Bank (ECB). The authors, I believe, are right, since in that stage the ECB enjoys decisional discretion in examining whether the applications comply with all relevant rules of EU law (See Articles 77 and 78 of the SSM Framework Regulation). Furthermore, Articles 80,81 and 83 of the SSM Framework Regulation make clear that the ECB may accept or reject draft national decisions for withdrawal of authorisations. In neither situation is the ECB automatically bound by national decisions or performs a role of minimal, formal control, as is the case in Borelli-type situations.

\section{Defending the Coherence of Borelli with the Broader Scenario of EU Constitutional Law}

If (EU) administrative law is to make a claim to be concretised (EU) constitutional law, its content must be held to be arguable for as imposed by or as derived from the constitution's principles. ${ }^{46}$ As was explained above,

The relevant rules are found in Council Regulation No 1024/2013 of 15 October 2013, conferring specific tasks on the European Central Bank concerning policies relating to the prudential supervision of credit institutions (SSM Regulation) and ECB Regulation No 468/2014 of 16 April 2014 (SSM Framework Regulation). For an analysis of the specific problems caused by the administrative procedures of the SSM, see A. Witte, 'The Application of national banking supervision law by the ECB: three parallel modes of executing EU law?', MJ (2014), $89 \mathrm{ff}$.

In this vein, though in the national context, see E. Schmidt-Aßmann, Das allgemeine Verwaltungsrecht als Ordnungsidee, 2nd ed. (Springer 2006), 11 and D. Ehlers, 'Verwaltung und Verwaltungsrecht im demokratischen und sozialen Rechtsstaat', in: H.-U. Erichsen \& D. Ehlers, Allgemeines Verwaltungsrecht, 14th ed. (De Gruyter 2010), 1 ff, 236. For the same line of thought, but from the perspective of EU administrative law, see T. von Danwitz, Europäisches Verwaltungsrecht (Berlin 2008), 141. 
derivability can plausibly serve as a criterion of normative coherence. Such derivability can exist in two types, dubbed by MacCormick as 'strong' and 'weak' derivability. Strong derivability expresses the notion that a decision or proposition can be seen as 'deductively derivable'. A proposition is deductively derivable when it is dictated by a pre-existent rule of the legal order in the sense that any other proposition or decision 'would be inconsistent with (...) some other binding rule, even in the light of all reasonable interpretive arguments applied to that rule' ${ }^{47}$ Normative coherence, as such, may be sufficed with weak derivability, meaning it only places onto interpreters the demand that their propositions are supported by reference to pre-existing provisions and principles. Therefore, constituting plausible interpretations of the positive law, and not unrestrained and unsupported invention of law. ${ }^{48}$

From here, it is not difficult to conclude that, when scholars make claims about whether a given administrative legal institution constitutes concretized constitutional law, either by being imposed by the constitution (strong derivability) or plausibly supported by constitutional norms (weak derivability), they are in fact making claims about the coherence between administrative and constitutional law. In this section, I will examine whether the two principles of the Borelli doctrine cohere with the EU constitutional order by testing whether they can be justified in the light of the founding principles of the EU constitutional order.

However, it should first be noted that academic reaction to Borelli was initially scarce, ${ }^{49}$ and that a considerable part of the studies on composite procedures have relied on merely descriptive approaches to the Case..$^{50}$ As opposed to examining what it actually implicates for the broader construction of European administrative law and administrative justice. However, one also finds very apprehensive responses to the case law.

Both the jurisdictional and substantive claims in Borelli are criticised by della Cananea, who argues that the CJEU's 'unexpected' decision to refuse to review the final act of the Commission risks the principle of effective judicial protection..$^{51}$ In the author's view, it seems, the CJEU should not have rejected Borelli's application, but looked into the whole irregular procedural path leading to the final decision. Indeed, concerns that the jurisdictional Borelli principle

47 N. MacCormick (n 12), 203.

48 Cfr. N. MacCormick (n 12), 203. Similarly, K. Kress (n 8), 503.

49 G. della Cananea (n 3), 197, note 8.

50 M. Dougan, National Remedies before the Court of Justice: Issues of Harmonisation and Differentiation (London 2004), 7-8 and 10 and J. Hofmann, 'Rechtsschutz und Haftung im Europäischen Verwaltungsverbund', in: E. Schmidt-Aßmann \& B. Schöndorf-Haubold, Der Europäische Verwaltungsverbund (Munich 2005) $353 \mathrm{ff}, 371-372$.

51 G. della Cananea (n 3), 198 and also in Diritto amministrativo europeo, 3rd ed. (Milan 2011), 166. 
leads to gaps in judicial protection are shared by a number of authors, ${ }^{52}$ some of which even claim that the Court in fact generated a situation where there was a denial of justice. ${ }^{53}$

A similar type of objection was raised by Caranta to the substantive Borelli principle.${ }^{54}$ Caranta emphasises that in all legal orders examined in his research, the invalidity of intermediate procedural measures leads to derivate invalidity of final administrative decisions. In the author's reaction, there is the suggestion that the substantive claim in Borelli was articulated because it would have otherwise been difficult to explain why the Commission's decision could not be reviewed. .5

Lastly, Gaja makes the claim that the Court should be considered to be entitled, in principle, 'to examine all the questions that are relevant for ascertaining the validity of the Community act - whether these questions relate to facts, EC law or national law', as 'there is no reason why it should not do so when it is necessary in order to exercise its judicial functions..$^{56}$ The argument made by Gaja continues with the claim that the reasons behind Foto-Frost and its assertion that only the CJEU should be able to annul a measure of EU law do not apply in the opposite sense, of precluding its jurisdiction over national intermediate measures. In Gaja's view, attributing to the CJEU the power to annul composite measures as the one in Borelli would not damage in any way the unity and the uniformity of EU law.

An alternative view is offered in this paper. It is submitted that the reasons advanced by the CJEU in the Foto-Frost ruling to exclude national judicial review of EU acts are the same which would lead us to see the two Borelli principles as a solution to judicial review of composite decision-making. A solution which adequately responds to the specific demands posed by EU constitutional law. Those reasons in Foto-Frost, if one may recall, are essentially the coherence of the EU system of judicial protection and the unity of EU law. ${ }^{57}$

As Koen Lenaerts rightfully points out, the competence of EU courts, much like the competences of the other EU institutions, is delimited by the principle

52 G. Mastrodonato, Procedimenti amministrativi composti nel diritto comunitario (Bari 2008), 116 and H. Hofmann (n 5), 158.

53 B.G. Matarella, 'Procedimenti e atti amministrativi', in: M. Chiti, Diritto amministrativo europeo (Milan 2013), 327 ff, 338. Similarly, L. Maeso Seco (n 18), 12 and 29, believes that the Borelli ruling creates a state of affairs in which private parties are caught up in a 'no-man's-land' between domestic and European administration and are deprived of the possibility to defend themselves in court.

54 R. Caranta (n 18), 760.

55 Ibid.

56 G. Gaja, 'Case C-6/99, Association Greenpeace France and Others v. Ministère de l'Agriculture et de la Pêche and Others. Judgment of the Full Court of 21 March 2000', CML Rev. (2000), $1427 \mathrm{ff}, 1431$

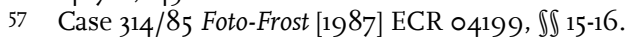


of conferral..$^{8}$ This means both that the definition of the jurisdiction of EU courts in the Treaties precludes the intrusion of national courts, and that the latter alone are entitled to exercise powers of judicial review where the Treaties do not establish the CJEU's competence. For this reason, to employ the words of the CJEU in Foto-Frost, 'the consideration of the necessary coherence of the system of judicial protection' of the Treaty dictates that only EU courts review EU measures and, conversely, only national Courts review national measures.

However, this is not a purely formal argument. It should be noted that to insist on the strict separation between national and European judicial power is to insist on the exclusive subjection of each authority to its own set of courts. It is to highlight that one's administration cannot be rendered accountable before any other judicial branch, ${ }^{59}$ and therefore, it is to secure its relative independence in the framework of a multilevel administrative system.

The Court has long conceived of the EU constitutional model of administration as a dualistic system, in the sense of being premised on a strict divide of spheres of administrative power, on a so-called Trennungsprinzip. ${ }^{60}$ On one hand, there is the EU Direct Administration: the Commission and its bureaucratic dependencies, the growingly complex array of European Agencies, and the Council. On the other hand, is Indirect Administration, ${ }^{61}$ consisting of Member States' authorities, structured according to their own national design, and involved in the implementation of EU law in a system of executive federalism. In that system, as a rule, the EU Institutions legislate and national bodies implement under the responsibility of the States. ${ }^{62}$ That the Court has consistently regarded national authorities as inserted into a dualistic model, and that their role as the main administrators of the EU results directly from the Treaties is illustrated in the strikingly recurrent usage of the Milchkontor-formula since the early 1980s. Summing up the case law, it had consistently built up over the previous decades, the Court notably declared that

$5^{8}$ K. Lenaerts, 'The Rule of Law and the Coherence of the Judicial System of the European Union', CML Rev. (2007), $1625 \mathrm{ff}$.

59 That the Court adheres to this line of thought, and that it goes both for EU and national bodies, is well illustrated in cases in which it explicitly draws a direct relation between responsibility for implementation and judicial control. See, for instance, Case 96/71 Haegeman [1972] ECR 01005 .

6o E. Schmidt-Aßmann, Das Allgemeine Verwaltungsrecht als Ordnungsidee: Grundlagen und Aufgaben der verwaltungsrechtlichen Systembildung, 2nd ed. (Springer 2006), 381.

61 The terms 'Direct' or 'Indirect' Administration used to this day to describe the two corresponding layers or poles of the Union administration seem to have been coined in 1970 by P. Pescatore, 'Das Zusammenwirken der Gemeinschaftsrechtsordnung mit den nationalen Rechtsordnungen', EuR (1970), $307 \mathrm{ff}, 309-312$.

62 T. von Danwitz (n 46), 307 and L. Azoulai, 'The Judge and the Community's Administrative Governance', in: C. Joerges \& R. Dehousse, Good Governance in Europe's Integrated Market (Oxford 2002), $109 \mathrm{ff}, 110$. 
'According to the general principles on which the institutional system of the Community is based and which govern the relations between the Community and the Member States, it is for the Member States, by virtue of Article 5 of the Treaty [now, article 4 (3) TEU], to ensure that Community regulations (...) are implemented within their territory' (emphasis added). ${ }^{63}$

The Court therefore seemed to embrace the doctrine according to which the Treaties' system, and in particular the principles regulating the relations between the EU and the states, had established a scheme of executive federalism for Indirect Administration premised on the German constitutional model. ${ }^{64}$ The doctrine that the EEC Treaty enshrined 'the principle of the Member States' executive,, ${ }_{55}$ akin 'to the principle of Länderexekutive in Article 83 GG', had long been defended by academics who were directly involved in the making of the EEC Treaty. ${ }^{66}$

As one can see, the CJEU's classic case law assumes that from the EU constitutional order one can derive a dualistic model of administrative authorities and judiciaries. ${ }^{67}$ Since Humblet, it has considered a 'principle of strict separation

63 Joined Cases 205 to 215/82 Deutsche Milchkontor [1983] ECR 02633, 『17. The same formula can be found in a multitude of posterior cases. See Cases C-290/91 Peter [1993] ECR I-2981, \8, C-292/97 Karlsson [2000] ECR I-02737, \27, C-285/93 Dominikanerinnen-Kloster Altenhohenau [1995] ECR I-04069, \& 26 and C-495/00 Visentin [2004] ECR I-02993, \39.

64 R. Schütze, 'From Rome to Lisbon: "Executive Federalism" in the (New) European Union', CMLRev., 47 (2010), $1385 \mathrm{ff}, 1405-1406$, points out the importance of the doctrine of autonomy and its limits for the analogy. See also K. Lenaerts, 'Some reflections on the separation of power in the Community', CML Rev. (1991), $11 \mathrm{ff}, 14-15$.

65 E. Wohlfahrt, annotation to Article 5 EEC, in: E. Wohlfahrt, U. Everling, H.J. Glaesner \& R. Sprung, Die Europäische Wirtschaftsgemeinschaft, Kommentar zum Vertrag, Vahlen (1960), 12.

66 E. Wohlfahrt, idem, annotation to Article 189 EEC, 517.

67 These considerations are key to understand Borelli as a case and as a doctrine. As Hofmann and Türk rightfully point out, the 'terminology used in the nascent field of EU administrative law is not yet established' (H. Hofmann \& A. Türk, 'Legal Challenges in EU administrative law by the move to an integrated administration', in: H. Hofmann \& A. Türk, Legal Challenges in EU Administrative Law (Elgar 2009), 355 ff, 358) and academics seem to refer to the divide between Direct and Indirect Administration in very different senses. For some, the dualistic scheme is a descriptive concept that relates to the ways in which, in practice, administrative authorities at national or EU level cooperate or engage in implementing activities without interacting with one another (E. Chiti., 'The Governance of Compliance', in: M. Cremona (Ed.), Compliance and the Enforcement of EU Law (Oxford 2012), $31 \mathrm{ff}$ ). Those who adhere to this perspective tend to consider that the traditional dichotomy between Direct and Indirect Administration has lost much of its significance or has indeed been 'abandoned' by existing forms of EU decision-making (M. Eliantonio (n 3), 77). Rather, the evolving cooperative practices in multilevel administrative implementation of EU laws and policies have accumulated to form a composite or integrated administration that stands in contrast with that model. One can, however, understand administrative dualism as a strictly legal construct, a doctrine which corresponded to the aspirations of the main political actors of integration, and which was stabilised by the Court in its reading of the EU constitution as the EU's standard model of administrative power. Administrative dualism is, from the perspective supported here, not a descriptive framework aimed at producing an accurate account on institutional facts, but normative legal framework, a legal regime resulting from the two-track system of spheres of administrative authority, of courts, and of the bodies of law governing each of them. According to this view, 
of powers of the Community Institutions and the authorities of the Member States' to exist alongside a 'principle of the strict separation between the powers of the Court (...) and of the national courts (...). ${ }^{68}$ In this model, each sphere of administrative power is institutionally and legally independent from each other, enjoys its own source of legitimacy, and is subject to its own set of courts. ${ }^{69}$ However, it is very important to be aware that, in the dualistic model presupposed in the CJEU's rulings, such independence does not equal the assumption that the two levels of administration should exercise their powers with their backs turned against each other. Rather, EU administrative dualism relies on a spirit of 'loyal independence' of the different administrative jurisdictions. Perhaps in no other ruling is it more evident than in Wünsche that the Court has long seen such 'loyal independence' as the constitutionally determined essence of the structure of administration in the EU. It was there that the Court found that, in the first common organisation of the markets in cereals, the forms of interaction between national administrative authorities and the Commission, 'both performing on their own initiative [in the French version: responsabilité their duties under Community law' but still acting in 'close cooperation', had been constructed 'in accordance with the structure of the Community' itself (emphasis added). ${ }^{70}$

However, the description of this two-track system would not be complete without adding that the ultimate guarantee of the separateness of the two administrative spheres comes from the fact that each one of them is subject to its own law, and to its own criteria of legality. While national authorities are subject

the dualistic model can easily accommodate the overwhelming majority of institutions, procedures and cooperative institutional practices usually described as composite administration (for a similar view, see J. Ziller, 'Introduction: les concepts d'administration directe, d'administration indirecte et de co-administration et les fondements du droit administrative européen', in: J.-B. Auby \& J. Dutheil de la Rochère, Droit Administratif Européen (Brussels 2007), 235 ff). Gradually, since the first EU regimes of relevance for administrative activity, nature of the cooperation between national and EU authorities shifted from the predominantly informal to more institutionalised, procedural forms of cooperation (this has been accurately observed in the field of structural funds by B. Schöndorf-Haubold, 'Common European Administration: the European Structural Funds', in: E. Schmidt-Aßmann, European Composite Administration (2011), $25 \mathrm{ff}, 53$. However, some forms of procedural cooperation - composite procedures - did far more than simply coordinating autonomous public powers with a view to ensure the effective implementation of Community policies. Instead, they crossed the boundaries of mutual collaboration into decisional interdependence by establishing decisional frameworks in which none of the two levels can validly adopt a final measure without previous procedural input from the other. Herein lies the fundamental constitutional problem of composite procedures: they display a structural inadequacy to the model of administration that the Court historically held to be ordered by EU constitutional law.

68 Case 6/60 Humblet [1960] ECR 00559, p. 568.

69 See L. Baroni, 'I Modelli di Amministrazione: Diretta, Indiretta e Coamministrazione', in: D.-U. Galetta, Diritto Amministrativo nell'Unione Europea: argomenti e materiali (Turin 2014), $231 \mathrm{ff}, 232$.

70 Case 76-70 Wünsche [1971] ECR 00393, 『10. 
to domestic administrative law, ${ }^{71}$ however Europeanised it may be, ${ }^{72}$ EU bodies are subject exclusively to the autonomous body of EU law, to the Treaties' 'own legal system'. ${ }^{73}$ Therefore, it follows that 'the validity of (...) measures [of EU bodies] can only be judged in the light of Community law', as 'recourse to the legal rules or concepts of national law in order to judge the validity of measures adopted by the institutions of the Community would have an adverse effect on the uniformity and efficacy', and therefore depriving them of their 'character as community law'. ${ }^{74}$

In these terms, as we can see, other than the concern with not invading national courts' sphere of competence, there seems to be an implicit concern in the articulation of the substantive Borelli principle. That concern is the safeguard of the very principle of the autonomy of the European legal order, which can be said to be the existential bedrock of EU law. ${ }^{75}$ And, through the defence of the autonomy of EU law, the invariability of its validity throughout the Member States, and thereby its unity and uniformity - its coherence - regardless of the Member State in which the composite procedure began.

The decisiveness of this concern is admittedly not entirely clear in the Borelli ruling. At first sight, the justification that the Court provides for the substantive Borelli principle seems to be one of a merely judicial procedural nature. In particular, the substantive dimension of the ruling appears to be depicted as a conceptual necessity in regard to the partition of judicial jurisdiction expressed in what I previously called the jurisdictional Borelli principle. However, it is not so obvious that it is plausible to draw substantive conclusions (the validity of a decision) from judicial-procedural premises (the exclusion of jurisdiction over a decision-making stage). Especially if one takes into account that both in Borelli and in subsequent case-law applicants argued that the challenged national intermediate measures had breached a rule of EU law. Assuming that Borelli was right about the procedure breaching Regulation 355/77, then it becomes indeed hard to see how the CJEU could have so easily admitted that a Commission decision is not made illegal when the requirements for its adoption are disregarded.

One must however read the CJEU's reference to the partition of judicial competences in the context of the significance of those rules in the development

71 On national administrative procedural autonomy, as opposed to judicial procedural autonomy, see for instance Case C-290/91 Peter [1993] ECR I-02981, \8.

72 On the increasing Europeanization of domestic laws and the gradual erosion of national procedural autonomy, see J.-B. Auby, 'About Europeanization of Domestic Judicial Review',

REALaw (2014/2), $19 \mathrm{ff}$.

73 Case 6-64 Costa v. E.N.E.L [1964] ECR 00585, p.594, 14-68 Walt Wilhelm, [1969] ECR oooo1, $\int 6$.

74 Case 11-70 Internationale Handelsgesellschaft [1970] ECR 01125, \3.

75 See U. Haltern, Europa und das Politische (Tubingen 2005), 281 and D. Chalmers \& L. Barroso, 'What Van Gend en Loos stands for', ICON (2014), $105 \mathrm{ff}$. 
of EU constitutional law. Since the earliest, seminal cases on the autonomy of the EU legal system, the limits of the jurisdiction of the CJEU have been invoked not simply as a justification for that autonomy, but as an expression of a general principle of independence of the EU legal order. ${ }^{76}$ The exclusive use in EU courts of EU legal sources, and the exclusiveness of review of EU legal acts, served a historical purpose of providing concrete arguments for the self-sufficiency and autonomy of the EU legal system. ${ }^{77}$

The constitutional contextualisation of the usage of provisions on the CJEU's jurisdiction should provide us with a suitable framework to understand what lies deeper within the reasoning of Borelli. That being the awareness that the simultaneous involvement of several autonomous legal orders in the making of the final measure makes its review far more complex from a constitutional standpoint. We have good reason to think that this concern was noticeably present in the Borelli case: Borelli was, as AG Darmon put it, about an administrative measure that had been 'drawn up in the context of two distinct legal systems' $^{78}$

The two Borelli principles were the only possible response the CJEU could have given, as it could have neither 'reinterpreted' its jurisdiction to extend it to domestic measures, ${ }^{79}$ nor opened the door to contamination effects from national intermediate measures to final European decisions.

To articulate anything different from the substantive Borelli principle would have amounted to, in practice, indirectly making the administrative law that is meant to govern national authorities (including strictly domestic rules), the standard of legality of the Commission's decisions before EU courts. In turn, this would have undermined the independence of EU legal acts from national sources as a basic corollary of autonomy of the legal order, ${ }^{8 \circ}$ and as a fundamental guarantee of integrity of the EU legal system. ${ }^{{ }_{1}}$

To accept that the unlawfulness of intermediate national measures could contaminate final measures of the Commission would amount to admitting that the validity of an EU legal act can be made dependent upon the validity of national legal acts. To this respect, given the variety of national classifications

76 See, for a paradigmatic case, Case $1 / 58$ Stork [1959] ECR ooo17.

77 For a more recent example of the usage of this reasoning, see Case T-187/11 Trabelsi [2013], \61.

78 AG Darmon, quoted at $\mathrm{n} 20$.

79 This is where I do not agree with L. Maeso Seco (n 18), 26 and 28. Even assuming that the Court, as the author points out, recognizes in the Borelli ruling that composite procedures form a tertium genus of European administration, this does not empower EU judges to reconstruct their jurisdictional limitations in order to fully review national authorities' actions.

80 For a discussion of the concept of autonomy of EU law, see J.H.H. Weiler, The Constitution of Europe: 'do the new clothes have an emperor?' and other essays on European Integration (Cambridge 1999), $286 \mathrm{ff}$ and A.J. Menéndez, 'Is European Union law a pluralist legal order?', in:

A.J. Menéndez \& J.E. Fossum, The Post-Sovereign Constellation: Law and Democracy in Neil D. MacCormick's legal and political theory (Oslo 2008), $233 \mathrm{ff}$.

81 See Case 6/64 Costa/Enel, $\mathbb{3}$. 
of administrative illegality into different forms of invalidity, several highly complex practical problems could arise ${ }^{82}$ Furthermore, using national law as a standard of legality for EU decisions is all the more problematic when the former can only be taken into account by the CJEU as mere fact and not as binding law. ${ }^{83}$

The substantive dimension of the Borelli doctrine is easier to understand when we consider the problems which would result from the acceptance of contamination effects based on the incompatibility of intermediate national measures with national administrative law. Nonetheless, contaminations based on their contrariety to EU law rules would not be much less problematic. It makes no difference that the adopted national intermediate measure breaches a rule enacted by an EU or national legislator.

To make the validity of legal acts of the EU dependent on national authorities' compliance with the law meant to govern their action, is to turn the legal constraints of national power into the legal constraints of the Commission's decisions through the backdoor. It is also making EU administrative decisionmaking power vulnerable to the poor exercise of national administrative power. Both notions are incompatible with the institutional autonomy of EU bodies from national power, which is one of the cornerstones of EU supranationality. ${ }^{84}$

Just as the substantive Borelli principle can be reconstructed as a corollary of constitutional separatism of legal orders and spheres of authority, the jurisdictional Borelli principles finds its first foundation in the separateness of national and EU judiciaries. The importance that the CJEU attached to the principle

82 Only to give an example, Portuguese and German administrative laws associate similar consequences to the qualification of absolute nullity of administrative acts, such as the possibility of challenge at any time. However, whereas Portuguese law (Art. 161/2 h) of the Code of Administrative Procedure) qualifies as absolutely null and void decisions adopted without the necessary deliberative quorum, German law explicitly excludes that qualification for decisions in the same circumstances $(\mathbb{4} 44$ (3), $3 \mathrm{VwVfG}$ ). If one admitted that an intermediate measure adopted without quorum could result in the illegality of a final European decision in composite procedures, how would an action for annulment function where the consequences of the irregularity are different in the Member States? Would the Court have to set aside the time limits in Article $2 \sigma_{3}(6)$ TFEU, depending on the Member State in which the procedure started? Such questions, in themselves, make clear to what extent the most important theoretical cornerstone of the autonomy of EU law - its 'Community' character - would be undermined if the Court had not elaborated the substantive Borelli principle. As R. Barents explains (The Autonomy of Community Law (The Hague 2004), 239-240), there is no autonomy of the legal order of the EU without its indivisibility, meaning the invariability of its validity (or of its forms of invalidity, I would add) and application throughout the territories of the Member States. This line of thought is present in many rulings of the Court. See, for instance, Case 48-71 Commission v Italian Republic, $\int 8$ : 'attainment of the objectives of the Community requires that the rules of Community law established by the Treaty itself or arising from procedures which it has instituted are fully applicable (...) with identical effects over the whole territory of the Community without the Member States being able to place any obstacles in the way'.

83 R. Barents, ibid., 265.

84 Compare with P. Pescatore, The law of integration: emergence of a new phenomenon in international relations, based on the experience of the European Communities (Leiden 1974), 51. 
in light of EU constitutional law can be clearly discerned in Association Greenpeace France. In the ruling, AG Mischo, looking back to the jurisdictional Borelli principle, found that a different solution would have amounted 'to call into question the division of powers between the national court and the Court (...) [which] would in [his] view be most unwise and would do nothing to promote the cause of respect for the rule of law within the Community legal order'. ${ }^{85}$

Regardless of how sound the constitutional justification of the position is the CJEU's refusal to review national intermediate administrative measures in composite procedures came at a price. EU courts cannot review the final measure, because it would imply reviewing domestic legal acts and accepting the relevance of their validity for the validity of EU measures. But national courts cannot review the final decision of the Commission either, since that would subvert the Treaty's system of judicial competences. It would thus seem that no judicial protection can be afforded at all.

It is here, however, that the jurisdictional Borelli principle shows its second foundation: the fundamental right to an effective judicial protection.

The CJEU is well aware that the practical implications of its constitutional restraints can result in a negative conflict of jurisdictions and ultimately in a denial of justice by both national and European Courts. Instead of keeping silent on the position of private parties, in the Borelli case law the CJEU insisted that no one should be deprived of remedies as a result of the separation of legal orders and judiciaries. ${ }^{86}$ The CJEU could have simply dismissed such a claim as inadmissible by invoking its own incompetence, as it had done before when presented with annulment claims against national measures. ${ }^{87}$ In a short ruling, and without further considerations. Instead, the CJEU explained in considerable depth why the national measure should be reviewable and affirmed that it would stand by the applicants' side if a national court refused to offer them judicial protection. In itself, this already suggests that the CJEU sees a relevant difference between the review of interlocutory domestic measures in composite procedures, and any other national legal acts.

For the CJEU to remain indifferent to the special vulnerability of individuals trapped in the vacuum between legal orders and judiciaries, it would have had to offer a solution that would have been grossly incoherent with its belief in being bound to draw inspiration from the Member States' standards of protection for fundamental rights. ${ }^{88}$ As well as with the proclamation of a complete

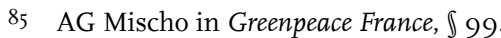

86 S. Cassese (n 3), 34 .

87 Cases 46/81 Benvenuto [1981] ECRoo809, 142/83 Nevas [1983] ECR 02969 and 285/90 Tsitouras [1991] ECR I-00787.

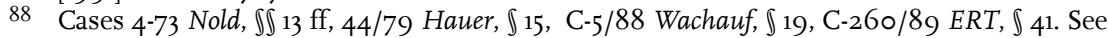
also U. Haltern (n 75) 359 ff. On the establishment of effective judicial protection as a general principle of law based on the constitutional traditions of the Member States, see Cases 222/86 Heylens, \\13 ff, 222/84 Johnston, \14, C-467/01 Eribrand, \41, C-432/05 Unibet, \37 and AG Poiares Maduro in Joined Cases C-402/05 P and C-415/05 P Kadi, $\mathbb{\int} 52$ : 'the right to effective judicial protection holds a prominent place in the firmament of fundamental rights'. 
system of judicial protection 'under the Treaties' constitutional charter' ${ }^{89}$ To remain indifferent, to the possibility of a denial of justice by both European and national courts, would have even jeopardised the CJEU's own credibility in its commitment to the respect for fundamental rights. ${ }^{90}$

In Borelli, the application of the two principles meant that the judicial protection of the company was denied by the CJEU. How, then, to explain the apparent paradox that the Case is quoted by EU courts as emblematic for effective judicial protection?

Concerning Borelli, it is rarely pointed-out that the CJEU's margin to afford, by itself, the judicial protection that the applicants sought was considerably reduced by the limits of its jurisdiction and by principles of EU constitutional law. Therefore, the great dilemma was to find a way out of the trap of competences and legal orders the applicant in Borelli found itself in, and to ensure that the principle of effective judicial protection would not be sacrificed. The jurisdictional Borelli principle expresses the method the CJEU adopted to solve this conflict.

On the whole, Borelli is, in my view, coherent with EU constitutional law because the CJEU detected a problem of articulation of principles and proposed a solution that it could plausibly defend as one finding sound support in the EU's constitutional principles. That solution was to defer to national courts the review of the intermediate measures.

89 Cases 294/83 Les Verts, \26, 314/85 Foto-Frost, \16, C-2/88 Zwartveld, 』 16, C-314/91 Weber,

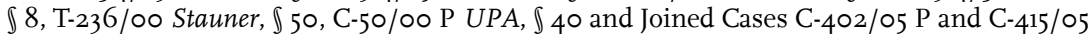
P Kadi, If 281-285.

$9 \circ$ One should bear in mind that the development of an EU protection of fundamental rights derives from a historical political imperative to ensure national judicial acceptance of the EU's - and the ECJ's - authority (J.H.H. Weiler (n 80), $107 \mathrm{ff}$ ). The Court's decidedness to clearly articulate how judicial protection from composite administration should be carried out echoes earlier concerns of safeguarding EU decision-making from the review of national courts. One can seriously doubt whether in the long run the Member States and their courts would accept the rise of a powerful administration that is anchored in a plurality of legal orders, but finds judicial limitation in none. The explicit articulation of a jurisdictional Borelli principle beyond the dismissal of Oleificio Borelli's annulment claim signalled to national courts that they could, under EU law, ensure the right to an effective judicial protection without reviewing the final decision. By doing so, the Court avoided that national courts undermined its exclusive jurisdiction to review the legality of EU measures by taking up for themselves the task of ensuring judicial protection when it would become apparent that no judiciary was competent to review the final measure. 


\section{The Coherence of the Borelli Doctrine with the Court's Case Law on the Reviewability of Intermediate Measures}

In Borelli, the only argument put forth by applicants for the illegality of the final measure was that it was adopted subsequent to a purportedly illegal domestic measure. The reasoning underlying the claim, that the final act of the procedure 'encapsulates all the decisions of the institutions and bodies involved in the procedure', has to be understood in light of the traditional administrative legal concept of procedural concentration.

According to this concept, which is present in both national and European administrative justice, only the challenge of definitive decisions affords the opportunity for the invocation of irregularities that occurred throughout the preceding procedure..$^{91}$ However, as we saw, if the CJEU had fully upheld procedural concentration and begun to review the final Commission measures in the Borelli case law, it would necessarily have had to betray both the limits of its jurisdiction and the autonomy of EU law. The partial sacrifice of the concept, resulting from these considerations, meant in practice the purge of national intermediate measures from review by EU courts, and therefore their inaptitude to produce the final European decision's invalidity through 'contamination effects'. It also means 'severing' the procedure in two for the purposes of treating intermediate domestic decisions as if they were the final outcome.

Possibly, the most powerful critique to the Borelli doctrine came from Herwig Hofmann. The author criticises the CJEU for displaying, in general, 'a tendency to refer cases to Member States' courts and oblige them to offer legal protection in much more lenient conditions than it itself is ready to give'..$^{22}$ In Hofmann's view, the jurisdictional Borelli principle is incoherent with the CJEU's own case law - notably, the IBM ruling, which established the inadmissibility of annulment claims against preparatory measures.

The claim I would like to make is the exact opposite. It is crucial that we look into the concrete framing and positive justification of the jurisdictional Borelli principle - the justification as to why national courts should review the relevant intermediate measures, as opposed to the justification as to why the CJEU should not. It is submitted here that one can actually see the construction of the jurisdictional Borelli principle as the extension to national administrative justice for the concepts and standards of annulment claims before the CJEU against EU bodies. By making a localised use of the technique of 'vertical

91 E. García de Enterría (note 30), 302 ff. In EU law, one can mention the classic works of A. Barav \& G. Vandersanden, Contentieux Communautaire (Brussels 1977), 144: 'les effets juridiques définitifs seraient produits par l'acte final dans lequel les mesures seraient incorporées et deviendraient attaquables à travers cet acte'.

92 H. Hofmann (n 5), 154. 
equivalence', the CJEU actually achieved coherence in judicial protection against composite decision-making procedures. The extension of those standards can be seen both in the delimitation of the kind of administrative measures that, in the course of a mixed procedure, should be regarded as reviewable, and in the criteria for standing implied in the jurisdictional Borelli principle.

The concept of vertical equivalence has been constructed by reference to the principle of equivalence as a limit to national procedural autonomy. The principle forbids national remedial rules from being less favourable to actions aimed at defending rights derived from EU law than the rules governing similar domestic actions. ${ }^{93}$ Vertical equivalence, by contrast, can be defined as the CJEU's technique of referring to the standards of judicial protection before European courts as the minimum standards of judicial protection it expects national courts to afford to individuals invoking EU law. ${ }^{94}$ As an example of this reasoning, national courts must receive liability claims based on a breach of EU law, even against legislators, because the Treaties do not differentiate the admissibility of similar claims according to the EU body generating the damages. ${ }^{95}$ Moreover, the CJEU cannot declare, by itself, a period of 60 days for annulment of national administrative acts as unreasonable or objectionable because that is the same time limit governing annulment claims against EU measures. ${ }^{96}$ It is understandable that the CJEU demands national courts to provide litigants, at the very least, with a degree of protection that is not inferior to the minimum protection they would obtain before EU courts in analogous proceedings. After all, the CJEU has historically insisted on a banner of coherence and completeness in the EU system of judicial protection. Indeed, in some cases, the aim to maintain a 'coherent system' of remedies is even explicitly mentioned as the reason why national courts should offer a level of protection that is, at least, analogous to the level of protection prescribed by the Treaties. ${ }^{97}$ Conversely, however, as some AGs have recently explained, EU law does not preclude

93 Just to name recent Case-law, see Joined Cases C-29/13 and C-30/13 Global Trans Lodzhistik,

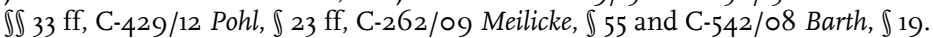

94 G. Greco (2009), 849 ff and 859. See also H. P. Nehl, Principles of Administrative Procedure in EC Law (London 1999), 7.

95 Joined Cases C-46/93 and C-48/93 Brasserie du Pêcheur, 『 $42 \mathrm{ff}$.

$9^{6}$ G. Greco (2009), 850-851. See Case C-312/93 Peterbroeck, \16 and AG Jacobs' Opinion in the ruling, $\int 30$ : 'the conclusion that the 60 day time-limit provided by the CIR is reasonable is supported by the analogy in Community law (...), under which the time-limit provided for the submission of an application (...) for the annulment of a Community act is two months'.

97 See Joined Cases C-143/88 and C-92/89 Zuckerfabrik Süderdithmarschen [1991] ECR I-00415: 'in the context of actions for annulment, Article 185 of the Treaty enables applicants to request suspension of enforcement of the contested act and empowers the Court to order such suspension. The coherence of the system of interim legal protection therefore requires that, in the context of a preliminary reference to be made by a national court, the latter should also be able to order suspension of enforcement of a national administrative measure based on a Community regulation, the legality of which is in dispute and which only the Court of Justice may declare to be invalid'. 
Member States from offering more generous conditions, for access to courts and judicial review, than EU law itself offers..$^{98}$ In fact, sometimes the CJEU has even demanded a degree of protection from the Member States that is more liberal than the degree it would provide under analogous circumstances. ${ }^{99}$

Vertical equivalence does not describe the development by the CJEU of a system of remedies against EU bodies based on judicial standards analogous to those it requires from Member States. Quite the opposite, it describes the fact that the CJEU has often set the remedial standards before EU Courts as the lowest threshold of judicial protection the States must ensure. The fact that the CJEU often demands that national courts provide a higher level of protection to individuals than it would provide at the EU level against EU bodies does not contradict that it demands a level of protection from Member States that is at least as generous as one would find in EU Courts, against EU bodies. ${ }^{100}$

Let us now turn to Hofmann's powerful argument against the coherence of Borelli with the techniques of judicial protection employed by the CJEU against EU bodies. Hofmann's claim that European Courts would not have reviewed intermediate measures analogous to the act adopted by the Italian authorities in Borelli seems to me to result from a reading that I do not share of the wording of the IBM ruling. It is on that ruling that Hofmann seeks substantiation for his claim. The segment Hofmann quotes is $₫ 10$ :

'In principle an act is open to review only if it is a measure definitely laying down the position of the Commission or the Council on the conclusion of that procedure, and not a provisional measure intended to pave the way for the final decision'. ${ }^{101}$

A close look at the IBM ruling, in particular at the Opinion of AG Slynn, ${ }^{102}$ and at its later development in case law, shows that the CJEU is actually formu-

98 See the opinion of AG Jääskinen in Case C-562/12 Liivimaa Lihaveis [2014], \50.

99 C. Kilpatrick, 'The Future of Remedies in Europe', in: C. Kilpatrick, T. Novitz \& P. Skidmore, The Future of Remedies in Europe (London 2000), $1 \mathrm{ff} 8-9$.

100 It is interesting to note how some national courts have also applied the reasoning of vertical equivalence without previous guidance from the Court. To give an example, the Italian Consiglio di Stato (Sez. VI - Ruling of 1oth of May 2011, no. 2755) decided by way of appeal on an action for annulment brought by an environmental NGO against Puglia's Regional Faunal Hunting Plan (piano faunistico venatorio). The Consiglio di Stato considered that to simply eliminate the challenged act would deprive Puglia of any regional discipline for hunting restrictions. The argument that followed was that, protection of the environment being a shared competence of the Member States and the EU, 'the standards of judicial protection cannot be different, depending on the acts being adopted at Community or national level'. The Consiglio therefore explicitly referred to Article 264 TFEU and to the Court's case-law declaring the illegality of EU measures but imposing on EU a moratorium to substitute them for lawful regimes (Case 81/72 Commission v. Council).

101 H. Hofmann (n 5), 154.

102 P. 2662. 
lating an argument based on the distinction between two kinds of intermediate measures. Some intermediate measures are of merely preparatory nature and only pave the way for the final decision. Others already bear legal effects that are capable of affecting the interests of the applicant 'by bringing about a distinct change in his legal position, ${ }^{103}$ either because they constitute the final act in a distinct sub-procedure that is binding in its effects, ${ }^{104}$ or because in substance they already entail the final decision. ${ }^{105}$ As AG Slynn explained,

'one should not examine too minutely whether a step marked the culmination of an administrative procedure', since 'it is not the preliminary or definitive nature of the examination which matters (...), but only the question whether the concrete legal effects intended by the measures in question are provisional ones.'

Intermediate measures may be subject to review when they constitute a gravamen for the applicant 'independently from the final decision' which formally closes the procedure. ${ }^{106}$ In the IBM Case, the CJEU established a substantive test to identify reviewable measures. A decision for the purposes of Article 263 TFEU does not need to take one of the forms of Article 288 TFEU. ${ }^{107}$ There is a difference between a decision in the sense of the final measure that is formally adopted in a procedure, and a decision in the sense of a measure that expresses an authority's definitive position on a matter. ${ }^{108}$

Although the IBM ruling is not quoted in Borelli, the language used by the $\mathrm{CJEU}$ in both cases is remarkably similar. What counts for the purposes of ju-

103 IBM, \9.

104 Joined Cases 8-11/66 Cimenteries, page 118, Case 53/85 Akzo, $\iint 16 \mathrm{ff}$, Joined cases T-213/01 and T-214/01 Österreichische Postsparkasse, II 64-65.

105 See Cases T-277/94 AITEC, \51 and T-37/92 BEUC, 『27.

106 A. Türk, Judicial Review in EU Law (Cheltenham 2009), 91 and H.-C. Röhl, 'Die Anfechtbare Entscheidung nach Art. 230 Abs. 4 EGV’, in: E. Schmidt-Aßmann \& B. Schöndorf-Haubold, Der Europäische Verwaltungsverbund (Munich 2005) 319 ff, 330. What matters for European Courts is that legal acts enjoy binding legal effects, even if they constitute non-final procedural measures, as the Court explained more clearly in Joined Cases T-377/00, T-379/00, T-380/00,

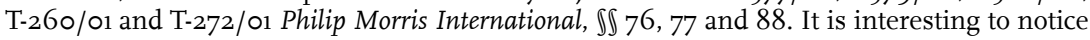
how early commentators found it implausible that the Court would ever differ from the Member States' administrative traditions and admit the annulment of non-final measures

(A. Tizzano, Note to Article 173, in: R. Quadri, Tratato Istitutivo della Comunità Economica Europea: Commentario, III (Milan 1965), $1241 \mathrm{ff}, 1259$ ).

107 H.-C. Röhl, passim and J. Bast, 'Handlungsformen und Rechtsschutz', in: A. von Bogdandy, Europäisches Verfassungsrecht, 2nd ed. (Tubingen 2009), $489 \mathrm{ff}, 518 \mathrm{ff}$. Though initially the forms in the two corresponding provisions were interpreted as meaning the same, the Court began in the 1970 to demand that an action for annulment 'be available in the case of all measures adopted by the Institutions, whatever their nature or form, which are intended to have legal effects' (22-70 Commission v. Council).

108 J. Schwarze, Annotation to Article 263 TFEU, in: J. Schwarze, EU-Kommentar, 3rd ed (BadenBaden 2012), $2176 \mathrm{ff}, 2280$. 
dicial review is that the challenged measures 'definitely ha[ve] an adverse effect' on the applicant. ${ }^{109}$ With this step in its reasoning, the CJEU completes the jurisdictional Borelli principle by giving indications both on the identification of reviewable intermediate measures and the assessment of the standing of applicants. What matters to the CJEU is that there is a national intermediate measure that bears the legal effects of predetermining the content of the final decision in the procedure, and that those legal effects are detrimental to the applicant's legal position. By making clear that individuals should be able to challenge nonfinal decisions of national administrative bodies because the gravamen affecting those individuals is imputable to those authorities' decisional input alone, the CJEU ends up establishing a criterion of standing that is symmetrical to direct concern. ${ }^{110}$ Particularly in the field of composite procedures - most notably, topdown composite procedures - the CJEU has refused to consider individuals directly concerned by Commission measures directed at national authorities when they leave discretion to the body adopting the final decision." ${ }^{\text {II }}$

The crucial justification of the CJEU for the establishment of the substantive reviewability test for administrative measures is noteworthy. Member States have to ensure effective judicial protection in these terms because the binding opinion from national authorities in the procedure, laid down in Regulation $355 / 77$, 'forms part of a procedure which leads to the adoption of a Community decision'. ${ }^{112}$ The qualification of composite procedures as European in nature is what justifies judicial review having to be carried out according to the European understanding of the criteria of reviewability of measures and standing that are compatible with the principle of effective judicial protection, as interpreted in EU law. Judicial review of national measures in composite procedures cannot depend on national idiosyncratic conceptions of what constitutes a reviewable administrative act. Otherwise that would make the regime of the challenge, against measures from European procedures, different from Member State to Member State. ${ }^{113}$ Therefore, it was advisable to adopt a common criterion, and

109 AG Darmon in Borelli, $\mathbb{3 2}$.

110 Compare with J.L. Cruz Vilaça, 'Effective Judicial Protection with Regard to Community Funds - May One be Directly Concerned by a Decision Addressed to a Member State?', in: J.L. Cruz Vilaça, EU Law and Integration: Twenty Years of Judicial Application of EU Law (London 2014), $166 \mathrm{ff}$. As the author notes, the same criterion of direct concern has been used itself in a somewhat inconsistent manner. However, this does not impede that there can be coherence between the criterion as it is generally enunciated by EU courts and the standard of standing for the annulment of national intermediate measures in bottom-up composite procedures. I am indebted to Mariolina Eliantonio for the valuable discussion on this point.

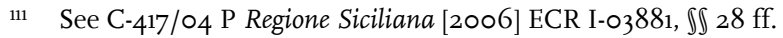

112 Borelli, $\iint 13$ and 15 .

113 Compare with Case 17/81 Pabst, \18: 'the legal classification in Community law of a national measure does not depend upon how that measure is viewed of appraised in the national context. The need to ensure that the provisions of the Treaty are applied in a uniform manner throughout the Community requires that they should be interpreted independently'. 
one that would be coherent with the one used by the CJEU, in the sense that it is guided by the same principles of judicial protection. That criterion, expressed in the IBM test, enables - though textually not in a self-evident way - the challenge of non-final measures.

The CJEU is aware of the limitations of its jurisdiction, and therefore deferred to national courts the task of reviewing measures using the same substantive test it endorses. Furthermore, it was those same limitations that led the CJEU to adapt the $I B M$ criterion, which by no means obliges private parties to challenge intermediate procedural measures. Individuals may do so, but they may also challenge the final decision. The jurisdictional Borelli principle entails an adaptation of the substantive test of $I B M$. That adaptation is justified by the CJEU's absence of jurisdiction over national measures, which makes the use of the technique of procedural concentration impossible. Because the Court may not examine whether the law was observed in all stages of the administrative procedure, private parties must invoke the irregularities of national intermediate measures that determine the procedure's outcome, and they must do so before national courts. . The exceptional admissibility of annulment claims against intermediate administrative measures adopted by the EU Direct Administration became the rule in European composite procedures in which national decisionmaking predominates.

\section{Conclusion: Coherence Between Administrative Reality and the Dualistic System of Judicial Protection?}

The intricate scenario of judicial protection set out by the CJEU is seen by some as symptomatic of the structural inadequacy of dualistic administrative justice to deal with composite decision-making. Criticism, in this case, is directed not at the case law itself, but at the very rules governing the EU's multilevel judiciary. For my part, I hold this criticism to be valid. While the Treaties' scheme of division of judicial competence and system of remedies have not undergone any reform that substantially questioned the dualistic system of administrative justice, the truth is that the EU legal landscape has known a remarkable increase in the sheer numbers and relevance of administrative procedures in which national and EU bodies do not decide in an independent way as the dualistic model assumes, but interdependently. The judicial system of the EU cannot coherently accommodate a significant amount of European administrative action anymore without ad hoc solutions like the Borelli doctrine. The principles guiding the dualistic system of independent (even if cooperative) spheres of administrative authority are simply not the same as those that inform the legislative creation of composite procedures, which are interdependent administrative decision-making processes. Accordingly, a judicial system that as- 
sumes dualistic authority to function is not coherent with the increasingly composite nature of administrative power in the EU.

The Borelli doctrine can, in my perspective, be seen as an adaptation to composite procedures of the case law on judicial review historically constructed by the CJEU. The two Borelli principles can serve as an instrument to avoid two things: On the one hand, damages to the independent character of the EU legal order and the subversion of the partition of judicial competences established in the Treaties. Then on the other, an absolute denial of justice resulting from the absence of any competent judiciary to review all stages of composite procedures.

However, Borelli remains as a correct solution, albeit a bad solution. It is true that the jurisdictional Borelli principle blocks the unacceptable possibility of judicially unfettered exercise of composite administrative authority, which would be a complete contradiction to the values of the rule of law and effective judicial protection. Nevertheless, it must be borne in mind that even if national courts successfully review intermediate measures, individuals will still have to turn to European Courts to challenge the final decision if it is issued in the meantime, thus duplicating annulment claims. ${ }^{114}$ In no way does this contradict the substantive Borelli principle, which only precludes contamination effects, as we saw. The validity of final decisions of the Commission still depends on the previous issue of national intermediate measures - but as a factual presupposition for their adoption to be possible. The annulment of the interlocutory domestic measure will leave the subsequent EU legal act without an essential presupposition for its valid enactment. In any event, the fact that in the current system of judicial protection individuals have to challenge the outcome of the same procedure twice, before two different courts, seems to me to be an undeniably suboptimal solution.

Proposals for reform of primary law are set forth by a number of scholars. Some hold that the CJEU should be given the power to assess the validity of national intermediate measures, provided that it does so against standards of EU law. ${ }^{115}$ Others support the institution of 'reverse references for preliminary rulings', in order to let national courts incidentally decide on the proper interpretation of national law and on the validity of intermediate measures when the CJEU has to deliver a ruling on the validity of Commission decisions based on national measures. ${ }^{116}$

114 A. Keessen, European Administrative Decisions: how the EU regulates products on the internal market (Groningen 2009), 153 and T. von Danwitz (n 46), 644.

115 A. Türk (n 106), 374-375.

${ }_{116}$ G. Gaja (n 56), 1431-1432, H. Hofmann (n 5), 159 ff. More recently, H. Hofmann \& M. Tighdi, 'Rights and Remedies in Implementation of EU Policies by Multi-Jurisdictional Networks', EPL (2014), 147 ff, 159 . 
The merits of these proposals are not in dispute here. But one should bear in mind that the peculiarities of the EU give rise to a series of obstacles for such far-reaching reforms. Given the fact that the Treaties need to go through a lengthy and complex process for reform, which, as history has proven, by no means comes with a guarantee of success, the EU system of administrative justice is remarkably rigid and resistant to evolution. This is indisputably one of the reasons why the EU's own system of judicial protection has grown 'increasingly out of line with the administrative laws of the Member States'. ${ }^{117}$ Furthermore, the proposition in particular to give EU courts the power to assess the validity of national measures could prove especially difficult from a political point of view. Another solution which could be debated is formalising the Borelli doctrine and thereby seeking to correct its flaws. Arguably, this could eventually be done even with an instrument of secondary law aimed at coordinating the two levels of administration. ${ }^{118}$ Such an instrument could make it mandatory for national authorities to notify to the eventual applicant the issue of domestic intermediate measures that are subsumable to the type envisioned by the jurisdictional Borelli principle, so as to facilitate judicial challenge before the EU body adopts the final decision. Otherwise, the legislator could establish standstill clauses providing for a short period between the adoption of that measure and the adoption of the final Commission decision so that individuals have the chance to challenge the latter. ${ }^{119}$ Lastly, and more boldly, such an instrument could establish the possibility to notify the Commission of national judicial decisions annulling intermediate measures and also establish a corresponding obligation for the Commission to withdraw any final decision it would have issued in the meantime, based on those measures. Of course, a reform of this kind could still not deliver the same result as a badly needed reform in primary law to bring harmony between EU administrative justice and the current shape of EU administration. Regardless of how politically difficult such a reform may be.

11 AG Jacobs in C-50/00 P UPA, $\mathbb{8} 85$.

118 The legal basis for such an instrument could be Article 197 TFEU, since it would surely not produce the harmonisation of national administrative laws, but rather schemes of coordination between EU bodies and the authorities of the Member States. Arguably, the EU legislator could find an implicit power to enact rules of the nature suggested in the text, since if the EU is competent to legislate administrative procedures in a given area, it may also coordinate the different jurisdictions involved in those decision-making procedures through mechanisms of this kind.

11 A possible problem of this solution would be the concrete choice for how long the standstill period should last. A longer period would make administrative decision-making very cumbersome and slow; a shorter period would make it difficult for individuals to prepare the claims they would present to court. I thank Professor Paola Chirulli for raising this point in the discussion of an earlier version of this paper. 